\title{
ANALISIS PENGENDALIAN PERSEDIAAN BAHAN BAKU PADA \\ UD. MIE STEVEN KAROMBASAN KOTA MANADO
}

\author{
Megawati Sengkeunaung \\ Tommy F. Lolowang \\ Nordy F. L. Waney
}

\begin{abstract}
This research aims to analyze raw material inventory at UD. Mie Steven. This research was conducted for four months from January to April 2017. The data used in this research are primary and secondary data. Primary data obtained through interviews with the company, while secondary data obtained from data that has been compiled in the form of documents from the company, data from BPS, previous research or from the internet. The data is processed using EOQ (Economic Order Quantity) method. The result of the research is known that the policy of raw material inventory control is done by UD. Mie Steven is not efficient yet. This is shown by the company's inventory cost is bigger than the result of analysis using EOQ method is 6,693 $\mathrm{Kg}$ with total cost of economical inventory Rp.11.325.500.
\end{abstract}

Keywords: control analysis, raw materials inventory, UD. Steven Noodles Karombasan, Manado City

\begin{abstract}
ABSTRAK
Penelitian ini bertujuan untuk menganalisis persediaan bahan baku pada UD. Mie Steven. Penelitian ini dilaksanakan selama empat bulan sejak bulan Januari sampai dengan April 2017. Data yang di gunakan dalam penelitian ini adalah data primer dan sekunder. Data primer diperoleh melalui wawancara dengan pihak perusahaan, sedangkan data sekunder di peroleh dari data yang telah tersusun dalam bentuk dokumen dari perusahaan, data dari BPS, hasil penelitian terdahulu maupun dari internet. Data yang diolah menggunakan metode EOQ (Economic Order Quantity). Hasil penelitian diketahui bahwa kebijakan pengendalian persediaan bahan baku yang di lakukan UD. Mie Steven belum efisien, Hal ini ditunjukkan dengan biaya persediaan perusahaan lebih besar dibanding hasil analisis menggunakan metode EOQ adalah $6.693 \mathrm{Kg}$ dengan biaya total persediaan ekonomis Rp.11.325.500.

Kata kunci: analisis pengendalian, persediaan bahan baku, UD. Mie Steven Karombasan, Kota Manado
\end{abstract}




\section{PENDAHULUAN}

\section{Latar Belakang}

Perkembangan dunia usaha di Provinsi Sulawesi Utara mulai menampakkan kemajuan yang pesat. Jumlah usaha kecil di Provinsi Sulawesi Utara mulai menunjukkan perkembangannya selama 3 tahun berturut, dimulai dari usaha kecil hingga usaha besar. Hal ini membuktikan bahwa usaha kecil mulai meningkat dan menarik daya-saing masyarakat untuk terus mengembangkan usaha kecil khususnya di Provinsi Sulawesi Utara dapat dilihat pada Tabel 1.

Tabel 1. Jumlah Usaha Mikro Kecil Menengah di Sulut Tahun 2014-2016

\begin{tabular}{lr}
\hline Tahun & Jumlah \\
\hline 2014 & 1.948 .126 \\
2015 & 2.089 .126 \\
2016 & 2.242 .155 \\
\hline
\end{tabular}

Sumber: BPS Sulut, 2016

Pengendalian persediaan bahan baku merupakan hal yang sangat penting, bahan baku merupakan salah satu faktor yang menjamin kelancaran proses produksi. Kegiatan pengendaliaan persediaan bahan baku mengatur tentang pelaksanaan pengandaan bahan baku yang diperlukan sesuai dengan jumlah yang dibutuhkan serta dengan biaya minimal, yang meliputi masalah pembelian bahan, menyimpan dan memelihara bahan, mengatur pengeluaran bahan saat di butuhkan dan juga mempertahankan persediaan dalam jumlah yang optimal (Veronica, 2013). Persediaan bahan baku suatu perusahaan adalah syarat dalam melakukan suatu proses produksi barang. Pengelolaan persediaan bahan baku yang tepat perusahaan tidak dapat melakukan kegiatan produksi yang baik. Persediaan bahan baku dilakukan dalam jumlah yang terlalu besar over stock akan menyebabkan beberapa kerugian. Kerugian yang pertama yaitu biaya penyimpanan yang ditanggung perusahaan akan semakin besar, perusahaan harus menanggung resiko kerusakan dalam penyimpanan. Kerugian yang kedua yaitu perusahaan harus mempersiapkan dana yang cukup besar untuk pembelian bahan baku. Persediaan bahan baku dalam jumlah yang terlalu besar akan meyebabkan alokasi modal untuk investasi pada bidang-bidang yang lain akan berkurang. Jumlah persediaan bahan baku yang terlalu besar justru akan menjadi penghalang dari kemajuan bidang-bidang yang lain dalam perusahaan tersebut.

Bahan baku (Raw Material) merupakan prioritas utama bagi suatu industri dalam proses produksinya. Perusahaan melakukan berbagai metode untuk mengelolah persediaan bahan baku. Prosedur dan cara pembelian bahan baku harus sesuai dengan kondisi perusahaan akan sangat menunjang kegiatan produksi. Perusahaan harus menentukan bahan baku agar jumlah pembeliaan dapat mencapai biaya persediaan minimum (Asori, 2010). UD. Mie Steven belum menerapkan manajemen analisis dengan menggunakan metode Economic Order Quantity dalam penanganan masalah Pengendalian Persediaan Bahan Baku, maka dengan uraian di atas peneliti ingin meneliti analisis pengedalian persediaan bahan baku pada UD. Mie Steven Karombasan Kota Manado.

\section{Rumusan Masalah}

Berdasarkan uraian pada latar belakang, maka yang menjadi rumusan masalah adalah Bagaimana pengendalian persediaan bahan baku yang dilakukan oleh UD. Mie Steven?

\section{Tujuan Penelitian}

Tujuan penelitian adalah untuk menganalisis pengendalian persediaan bahan baku yang dilakukan oleh UD. Mie Steven.

\section{Manfaat Penelitian}

Penelitiaan ini diharapkan bermanfaat bagi peneliti untuk memberikan informasi dan masukan yang dapat digunakan untuk kepentingan bahan penelitian lanjutan.

\section{METODOLOGI PENELITIAN}

\section{Lokasi dan Waktu Penelitian}

Penelitian ini dilaksanakan selama 4 bulan yaitu dari bulan Januari sampai dengan April 2017 dan berlokasi di UD. Mie Steven Karombasan Utara Manado. 


\section{Metode Pengumpulan Data}

Data yang digunakan dalam penelitian ini adalah data primer dan sekunder. Data primer didapat melalui pengamatan langsung dilapangan serta wawancara secara langsung. Wawancara dilakukan dengan pihak perusahaan. Data sekunder diperoleh dari literatul yang relevan, data dari BPS, serta dokumen dan laporan yang dimiliki oleh perusahaan dan instansi terkait.

\section{Konsep Pengukuran Variabel}

Ada variabel yang diteliti adalah :

1. Kuantitas Pemesanan yang Ekonomis (Economic Order Quantity)

2. Biaya Pemesanan (Ordering Cost), biaya yang keluar sehubungan dengan pemesanan bahan baku.

3. Biaya Penyimpanan (Carrying Cost) adalah biaya yang dikeluarkan sehubungan dengan penyimpanan bahan baku.

4. Biaya Total Persediaan (Total Inventory Cost). Merupakan penjumlahan total biaya pemesanan dan total biaya penyimpanan bahan baku (Rp).

5. Pemesanan Ulang (Reorder Cycle), saat atau waktu tertentu perusahaan harus mengadakan pemesanan bahan dasar kembali.

\section{Metode Analisis Data}

Analisis data yang digunakan dalam penelitian ini deskriptif dan menggunakan metode Economic Order Quantity (EOQ).

Economic Order Quantity $=\sqrt{\frac{2 D s}{h}}$

Ket :

D = Kebutuhan dalam suatu periode perencanaan $(\mathrm{kg})$

$\mathrm{S} \quad$ = Biaya yang dikeluarkan setiap kali pemesanan (Rp)

$\mathrm{H}=$ Biaya Penyimpanan setiap unit persediaan (Rp)

\section{Biaya Simpan $=\left(\frac{Q}{2}\right) h$}

Ket :

$\mathrm{Q}=$ Jumlah bahan baku yang dipesan setiap kali pemesanan $(\mathrm{kg})$

$\mathrm{H} \quad$ = Biaya penyimpanan $(\mathrm{Rp})$
Biaya Pesan $=\left(\frac{D}{Q}\right) s$

Ket

D = Kebutuhan dalam suatu periode perencanaan $(\mathrm{kg})$

$\mathrm{Q} \quad=$ Jumlah bahan baku yang dipesan setiapkali pesanan $(\mathrm{kg})$

$\mathrm{S} \quad=$ Biaya yang dikeluarkan setiap kali pemesanan (Rp)

Total Biaya Persediaan $($ TIC $)=B P+B S$

Ket. :

$\mathrm{BP} \quad=$ Biaya pesan $(\mathrm{Rp})$

BS = Biaya simpan (Rp)

Pemesanan Ulang : $P=\frac{o}{Q}$

Ket. :

$\mathrm{P} \quad=$ Siklus Pesan Ulang

$\mathrm{O} \quad=$ Kebutuhan dalam suatu periode suatu perencanaan $(\mathrm{kg})$

$\mathrm{Q}=$ = Jumlah Bahan baku yang dipesan setiap kali pemesanan $(\mathrm{kg})$

Periode Waktu Setiap kali Pemesanan Ulang $\mathbf{Y}=\frac{W}{P}$

Ket

$\mathrm{Y} \quad=$ Periode waktu perencanaan (Hari)

$\mathrm{P} \quad=$ Siklus Pemesanan Ulang

$\mathrm{W} \quad=$ Periode waktu setiap siklus pemesanan ulang (Hari)

Tingkat Pemakaian saat Pemesanan Ulang : $\Delta \frac{D}{\Delta W} \Delta \frac{Q}{\Delta Y}$

Ket :

D : Kebutuhan dalam suatu periode perencanaan $(\mathrm{Kg})$

$\Delta \mathrm{W} \quad$ : Periode waktu setiap siklus pemesanan ulang $(\mathrm{Kg})$

Q : Jumlah pemesanan persediaan $(\mathrm{Kg})$

$\Delta \mathrm{Y} \quad$ : Periode waktu perencanaan (Hari)

\section{HASIL DAN PEMBAHASAN}

\section{Sejarah Umum UD. Mie Steven}

UD. Mie Steven merupakan pengembangan dari UD. Sehati yang dimiliki oleh Bapak Yoce Umboh. Beliau mulai merintis usahanya pada tahun 1970-an dan belum memiliki nama perusahaan. Setelah usaha berjalan hingga tahun 1990-an barulah perusahaan tersebut memiliki nama yaitu UD. Sehati. UD. Sehati juga mulai mengembangkan usahanya sehingga 
memiliki anak perusahaan yaitu UD. Mie Steven dan Mie Etty. UD. Mie Steven berdiri pada tahun 2003 yang dikembangkan oleh bapak Steven Umboh yang merupakan anak dari pemilik UD. Sehati. Sehingga usaha ini dari awal berdiri sampai sekarang boleh berjalan hingga 47 tahun. UD. Mie Steven ini terletak di Kelurahan Karombasan Utara dan Berada pada Kawasan Pasar Pinangsungkulan (Karombasan) Kota Manado. UD. Mie Steven Juga Sudah Memiliki 9 orang tenaga kerja 4 orang laki-laki dan 5 orang perempuan.

\section{Pengendalian Persediaan Bahan Baku}

Syarat kerja sama yang dilakukan antara UD. Mie Steven dengan Pihak distributor yaitu bahan baku yang dipesan atau dibeli harus tiba dalam kurung waktu 3 hari setelah pemesanan. Jika pemesanan atau pembelian langsung dilakukan oleh pihak perusahaan biasanya sebagian bahan baku langsung dibawah dengan menggunakan kendaraan Pribadi. Dari proses pengendaliaan persediaan bahan baku maka ada biaya yang dikeluarkan untuk setiap kali pengantaran bahan baku sampai ke gudang persediaan UD. Mie Steven yaitu untuk sekali pengantaran Rp. 250.000 dan alat transportasi yang digunakan yaitu kendaran beroda 4 (empat).

\section{Analisis Persediaan Metode EOQ (Economic Order Quantity)}

Pembelian dan penggunaan Bahan Baku adalah jumlah pembelian dan penggunaan tepung terigu pada tahun 2016 oleh UD. Mie Steven dapat dilihat pada Tabel 2. Tabel 2 menunjukkan bahwa pembelian dan penggunaan bahan baku yang digunakan UD. mie Steven selama tahun 2016. Pembelian terendah terjadi pada bulan Januari dikarenakan masih tersisah bahan baku dari tahun sebelumnya. Sedangkan pada bulan Februari sampai Agustus perbandingan tidak terlalu jauh,dan bulan September sampai desember mengalami peningkatan. Sehingga Total Pembelian bahan baku pada tahun 2016 mulai dari bulan Januari sampai Desember adalah sebesar $233.975 \mathrm{~kg}$ dan total penggunaan bahan baku adalah sebesar $228.700 \mathrm{~kg}$ Sehingga selisinya kelebihan bahan baku dengan total sebesar $5.275 \mathrm{~kg}$.
Tabel 2. Data Pembelian dan Penggunaan Bahan Baku Tepung Terigu UD.Mie Steven Tahun 2016

\begin{tabular}{lccc}
\hline Bulan & $\begin{array}{c}\text { Pembelian } \\
(\mathbf{k g})\end{array}$ & $\begin{array}{c}\text { Penggunaan } \\
(\mathbf{k g})\end{array}$ & $+\mathbf{+} \mathbf{( K g )}$ \\
\hline Januari & 17.500 & 19.375 & $(1.875)$ \\
Februari & 18.250 & 18.125 & 125 \\
Maret & 19.450 & 19.375 & 75 \\
April & 19.525 & 18.750 & 775 \\
Mei & 19.625 & 19.325 & 300 \\
Juni & 19.650 & 18.750 & 900 \\
Juli & 19.750 & 19.375 & 375 \\
Agustus & 19.875 & 19.375 & 500 \\
September & 20.000 & 18.750 & 1.250 \\
Oktober & 20.025 & 19.375 & 650 \\
November & 20.075 & 18.750 & 1.325 \\
Desember & 20.250 & 19.375 & 875 \\
\hline \multicolumn{1}{c}{ Total } & $\mathbf{2 3 3 . 9 7 5}$ & $\mathbf{2 2 8 . 7 0 0}$ & $\mathbf{5 . 2 7 5}$ \\
\hline Rata-rata & $\mathbf{1 9 . 4 9 8}$ & $\mathbf{1 9 . 0 5 8}$ & $\mathbf{4 4 0}$ \\
\hline Sumber: UD. Mie Steven, 2016 &
\end{tabular}

Untuk kelebihan bahan baku pihak perusahaan mengantisipasi untuk persiapan persediaan diawal tahun berikutnya.

a. Biaya Pemesanan

Biaya Pemesanan Adalah Biaya yang dikeluarkan pada saat pemesanan bahan baku pada agen penjualan. Biaya pemesanan terdiri dari biaya telepon, biaya pembelian bahan baku, biaya transportasi, biaya tenaga kerja dapat dilihat pada Tabel 3.

Tabel 3. Biaya Pemesanan Tepung Terigu di UD. Mie Steven Tahun 2016

\begin{tabular}{lc}
\hline Jenis Biaya & Rp \\
\hline Biaya Telepon & 864.000 \\
Biaya Pengadaan Bahan Baku & 10.800 .000 \\
\hline Total & $\mathbf{1 1 . 6 6 4 . 0 0 0}$ \\
\hline Sumber : UD. Mie Steven, 2016 &
\end{tabular}

Tabel 3 menunjukkan bahwa biaya yang dikeluarkan perusahaan adalah sebesar $\mathrm{Rp}$. 162.000 yang di peroleh dari total biaya pemesanan yang dikeluarkan perusahaan pada tahun 2016 dibagi dengan frekuensi pemesanan yang dilakukan pada tahun 2016 yaitu 72 kali.

1) Biaya telepon, yaitu biaya yang timbul karena pemakaian jasa komunikasi untuk pemesanan bahan baku tepung terigu. Total Biaya telepon pada tahun 2016 adalah sebesar Rp.864.000.

2) Biaya Pengadaan Bahan baku, yaitu biaya yang dikeluarkan oleh perusahaan pada saat pembelian bahan baku tepung terigu. Total biaya yang 
dikeluarkan pada tahun 2016 adalah Rp.10.800.000.

b. Biaya Penyimpanan

Merupakan biaya-biaya yang dikeluarkan karena perusahaan melakukan penyimpanan dalam persediaan bahan baku untuk jangka waktu tertentu. Adapun yang termasuk dalam biaya penyimpanan antara lain, biaya penerangan dan biaya pemeliharaan,biaya pajak. Berikut ini adalah tabel yang menyajikan biaya penyimpanan yang dilakukan oleh UD. Mie Steven.

Tabel 4. Biaya Penyimpanan Tepung Terigu di UD. Mie Steven Tahun 2016

\begin{tabular}{lr}
\hline Jenis Biaya & \multicolumn{1}{c}{ Rp } \\
\hline Biaya Penerangan & 24.000 .000 \\
Biaya Pemeliharaan & 6.000 .000 \\
Biaya Pajak & 33.000 .000 \\
\hline Sumber : UD. Mie Steven, 2016
\end{tabular}

Tabel 4 menunjukkan bahwa terdapat 3 jenis biaya yaitu biaya penerangan,biaya pemeliharaan dan biaya pajak. Biaya penyimpanan yang dikeluarkan oleh UD. Mie Steven adalah Rp. 1.692. Biaya ini di dapat dari pembagian antara total biaya penyimpanan dengan hasil rata-rata pembelian bahan baku tahun 2016 sebesar $19.498 \mathrm{~kg}$.

a. Biaya Penerangan, yaitu biaya yang dikeluarkan perusahaan untuk pembayaran rekening listrik dengan total pembayaran pada tahun 2016 adalah sebesar Rp.24.000.000.

b. Biaya Pemeliharaan, yaitu biaya yang dikeluarkan perusahaan untuk pemeliharaan peralatan dan pembersihan dengan total biaya pemeliharaan adalah sebesar Rp.6.000.000.

c. Biaya Pajak yaitu biaya yang dikeluarkan untuk pembayaran pajak bangunan dalam 1 tahun. Total biaya Pajak pada tahun 2016 adalah sebesar Rp. 3.000.000.

\section{Hasil Analisis}

\section{Perhitungan EOQ}

Jumlah penggunaan bahan baku tepung terigu, biaya pemesanan setiap kali melakukan pemesanan dan besarnya biaya penyimpanan per unit pada UD Mie Steven tahun 2016 dapat dilihat pada Tabel 5.

Tabel 5. Penggunaan Bahan Baku, Biaya Pemesanan dan Biaya Penyimpanan di UD. Mie Steven 2016

\begin{tabular}{lc}
\hline Uraian & $\mathbf{2 0 1 6}$ \\
\hline Kuantitas (kg) & 233.975 \\
Biaya Pemesanan (Rp) & 162.000 \\
Biaya Penyimpanan (Rp) & 1.692 \\
\hline
\end{tabular}

Sumber : UD. Mie Steven, 2016

Tabel 5 menunjukkan bahwa biaya penggunaan bahan baku, biaya pemesanan dan biaya penyimpanan pada tahun 2016 didapatkan dengan perincian sebagai berikut:

a. Kuantitas $(\mathrm{Kg})$ didapatkan dari jumlah total penggunaan bahan baku sebesar $233.975 \mathrm{~kg}$ pada tahun 2016.

b. Biaya Pemesanan didapatkan dari jumlah total biaya Pemesanan tahun 2016 adalah sebesar Rp.162.000.

c. Biaya Penyimpanan didapatkan dari jumlah total biaya pemesanan tahun 2016 adalah sebesar Rp.1.692.

\section{Economic Order Quantity}

$$
\begin{aligned}
\sqrt{\frac{2 D s}{h}} & =\sqrt{\frac{2 \times 233.975 \times 162.000}{1.692}} \\
& =6.693 \mathrm{~kg}
\end{aligned}
$$

Jumlah pembelian bahan baku yang optimal setiap kali pesan pada tahun 2016 adalah sebesar $6.693 \mathrm{~kg}$.

\section{Perhitungan Pemesanan Ulang (Reorder Cycle)}

Pemesanan ulang merupakan jumlah bahan bahan baku yang dipesan ulang dalam suatu periode perencanaan dan dihitung sesuai rumus dan hasil adalah

$$
=\mathrm{P}=\frac{D}{Q}
$$

$$
=\frac{233.975}{6.693}
$$

$=34$ kali pemesanan ulang 
Frekuensi pembelian bahan baku yang diperlukan UD.Mie Steven adalah sebanyak 34 kali pemesanan.

\section{Periode Waktu Setiap Kali Pemesan Ulang}

Periode waktu setiap kali pesan merupakan waktu perencanaan atau berapa hari waktu yang diperlukan setiap kali pemesananan dan hasilnya adalah:

$$
\begin{aligned}
Y & =\frac{W}{P} \\
& =\frac{364}{34} \\
& =10 \text { hari }
\end{aligned}
$$

Panjangnya waktu setiap kali pemesanan ulang adalah 10 hari.

\section{Tingkat Pemakaian saat Pemesanan Ulang :}

$$
\Delta \frac{D}{\Delta W} \Delta \frac{Q}{\Delta \boldsymbol{Y}}
$$

Tingkat pemakaian saat pemesanan ulang merupakan kebutuhan dalam suatu periode waktu sesuai dengan tingkat pemakaian saat akan dilakukan pemesanan ulang hasilnya yaitu $\mathrm{Q}=6.693$ dan $\mathrm{Y}=10$ hari hasil pemesanan dan tingkat pemakaian perhari adalah $669 \mathrm{~kg}$, dengan lead time waktu adalah 3 hari, maka pemakaian selama lead time adalah $3 \times 669 \mathrm{~kg}=2.007 \mathrm{~kg}$. Dengan demikian saat memesan ulang (Reoder Point) adalah pada saat persediaan tinggal $2.007 \mathrm{Kg}$.

\section{Perhitungan Total Biaya Persediaan (TIC)}

Mengetahui total biaya persediaan bahan baku minimal yang diperlukan perusahaan dengan menggunakan perhitungan EOQ untuk penghematan biaya persediaan perusahaan.

$$
\begin{aligned}
\mathbf{T I C} & =(\mathbf{D} / \mathbf{Q}) \mathbf{S}+(\mathbf{Q} / \mathbf{2}) \mathbf{h} \\
& =\frac{233.975}{6.693}(\mathrm{Rp} .162 .000)+\frac{6.693}{2}(\mathrm{Rp} .1 .692)
\end{aligned}
$$

$$
\begin{aligned}
& =\operatorname{Rp} .5 .663 .222+\operatorname{Rp} 5.662 .278 \\
& =\text { Rp. } 11.325 .500 \\
& \text { Total Biaya persediaan yang di }
\end{aligned}
$$
keluarkan UD. Mie Steven menurut metode EOQ pada tahun 2016 adalah sebesar Rp.11.325.500. Sedangkan perhitungan total biaya persediaan menurut UD. Mie Steven akan di hitung dengan menggunakan rumus sebagai berikut:

TIC $=($ Penggunaan rata-rata Bahan Baku $)(\mathrm{h})+$ (s) (F)

$$
\begin{aligned}
\text { TIC } & =(19.058 \times 1.692)+162.000 \times 72) \\
& =\text { Rp. } 32.246 .136+\text { Rp. Rp. } 11.664 .000 \\
& =\text { Rp. } 43.910 .136
\end{aligned}
$$

Jadi, total biaya persediaan menurut kebijakan UD. Mie steven pada tahun 2016 adalah sebesar Rp. 43.910.136.

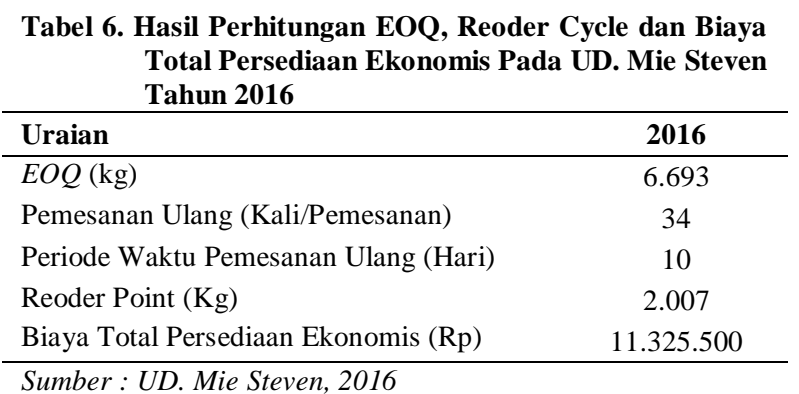

Tabel 6 menunjukkan bahwa pemesanan bahan baku yang ekonomis adalah sebanyak 6.693 kg dengan Frekuensi pesanan bahan baku sebanyak 34 kali dengan periode waktu pemesanan ulang adalah 10 hari dan waktu pemesanan ulang (Reoder Point) pada saat persediaan tinggal $2.007 \mathrm{~kg}$ dengan biaya total persediaan ekonomis sebesar Rp.11.325.500

\section{KESIMPULAN DAN SARAN}

\section{Kesimpulan}

Kebijakan pengendalian persediaan bahan baku yang dilakukan oleh UD.Mie Steven belum efisisen, begitu pula dengan biaya pemesanan yang belum ekonomis, hal ini ditunjukkan dengan biaya persediaan perusahaan lebih besar dibanding dengan hasil analisis menggunakan 
metode EOQ. Pemesanan tepung terigu yang optimal setiap kali pesan menurut metode EOQ adalah $6.693 \mathrm{~kg}$ dengan biaya total persediaan ekonomis yang sebesar Rp.11.325.500.

\section{Saran}

Hasil penelitian ini memperlihatkan bahwa biaya pengandaan bahan baku UD. Mie Steven masih dapat diminimumkan. Dan UD. Mie Steven sebaiknya melakukan pemesanan bahan baku secara optimal sehingga biaya persediaan bahan baku dapat diminimalkan, dengan menggunakan alat bantu hitung EOQ (Economic Order Quantity.

\section{DAFTAR PUSTAKA}

Anny, Antonius. 2016. Analisis Persediaan Bahan Baku Kelapa Pada PT. Dimembe Nyiur Agripro (DNA) Di Desa Tetey Jaga 1 Kecamatan Dimembe Kabupaten Minahasa Utara. Skripsi. Fakultas Pertanian Universitas Sam Ratulangi. Manado.

Asori,H., 2010. Analisis Pengendalian Persediaan Bahan Baku Kayu Sengon PT. Abhirama Kresna Dengan Metode EOQ .Skripsi.Program Studi Manajemen Industri Fakultas Ekonomi Universitas Sebelas Maret Surakarta.

Badan Pusat Statistik, 2014. Sulawesi Utara Dalam Angka Tahun 2014. BPS, Manado.

Badan Pusat Statistik, 2015. Sulawesi Utara Dalam Angka Tahun 2015. BPS, Manado.

Badan Pusat Statistik, 2016.Sulawesi Utara Dalam Angka Tahun 2016. BPS, Manado.

Fjrin, Eldwidho H. 2015. Analisis Pengendalian Persediaan Bahan Baku Dengan Menggunakan Metode Economic Order Quantity (EOQ) Pada Perusahaa Roti Bonansa. Skripsi. Fakultas Ekonomi Universitas Negeri Semarang.

Fitriani. 2013. Analisis Pengendalian Persediaan Bahan Baku di PT. Eastern Pearl Flour Mills Makassar. Skripsi. Fakultas Ekonomi dan Bisnis Universitas Hasanuddin. Makassar.

Haming, M. 2007. Manajemen Produksi Modern Operasi Manufaktur dan Jasa. Penerbit : Bumi Aksara. Jakarta.
Handoko. T H., 2015. Dasar-Dasar Manajemen Produksi dan Operasi. BPFE, Yogyakarta.

Jani, Rahman. Analisis Pengendalian Persediaan Bahan Baku Pakan Ternak Sapi Dalam Rangka Efisiensi Dengan Menggunakan Diagram Sebab Akibat. Skripsi. Fakultas Ekonomi dan Bisnis. Universitas Diponegoro. Semarang.

Karumarudin, Rizki. 2015. Analisis Pengendalian Persediaan Tepung Terigu Dan Gula Pasir Dengan Menggunakan Metode Economic Order $Q$ "ty Pada Ibu Basuki Bakery. Skrips zultas Ekonomi Univertitas Negeri Semarang.

Malik, Muh. Taufik. 2013. Analisis Persediaan Bahan Baku Kertas Menggunakan Metode EOQ (Economic Order Quantity) Pada Harian Tribun Timur Makassar. Skripsi. Fakultas Ekonomi dan Bisnis Universitas Hasanuddin. Makassar.

Maulana, Ardy. 2015. Analisis Efisiensi Persediaan Bahan Baku Susu Sapi Murni Dengan Menggunakan Metode Economic Order Quantity Pada Soto Sedeep. Skripsi. Fakultas Ekonomika dan Bisnis Universitas Diponegoro. Semarang.

Montolalu. L A. 2016. Analisis Pengendalian Persediaan Bahan Baku Kelapa Pada Industri Tepung Kelapa (Studi Kasus Pada PT.Royal Coconut). Skripsi Fakultas Pertanian Universitas Sam Ratulangi. Manado.

Rangkuti, Freddy. 2004. Manajemen Persediaan Aplikasi Bidang Bisnis. PT. Raja Grafindo Persada. Jakarta.

Simbar, Mutiara. 2014. Analisis Pengendalian Persediaan Bahan Baku Kayu Cempaka Pada Industri Mebel Dengan Menggunakan Metode EOQ. Skripsi. Fakultas Pertanian Universitas Sam Ratulangi. Manado.

Siswanto, H. B. 2008. Pengantar Manajemen. PT. Bumi Aksara. Jakarta.

Suhartanti. R. 2009. Analisis Pengendalian Persediaan Bahan Baku dengan Model Backorder pada Cv. Cihanjuang Inti Teknik. Skripsi. Jakarta.

Tatuh. S. Daniel.2015. Analisis Pengelolaan Persediaan Beras di PT. Semarak Kota Manado. Skripsi. Fakultas Pertanian Universitas Sam Ratulangi. Manado. 
Veronica, Mieke Adiyastri. 2013. Analisis Pengendalian Persediaan Bahan Baku Beras Dengan Metode Ecinomic Order Quantity (EOQ) Multi Produk Guna Meminimumkan Biaya Pada CV.Lumbung Tani Makmur Di Banyuwangi. Skripsi. Fakultas Ekonomi. Universitas Jember.
Wahyuningsish, Restu. 2011. Analisis Pengendaliaan Persediaan Bahan Baku Pada PT. DASGAP ENDURA EATORE Di Kawasan Industri Sentul, Bogor. Universitas Islam Negeri Syarif Hidayatullah. Jakarta.

Yamit, J., 2007. Manajemen Kuantitatif Untuk Bisnis (Operation Research). BPFE, Yogyakarta 